\title{
Flipping an on-campus general English course: a focus on technology complexity of instruction and learners' levels of impulsivity
}

\author{
Shakiba Zarrinfard ${ }^{1}$, Mehrak Rahimi $^{2^{*}}$ (I) and Ahmad Mohseny ${ }^{1}$
}

\author{
${ }^{*}$ Correspondence: \\ mehrakrahimi@yahoo.com; \\ rahimi@sru.ac.ir \\ ${ }^{2}$ English Department, Faculty \\ of Humanities, Shahid Rajaee \\ Teacher Training University, \\ Lavizan, Tehran 1678815811, \\ Iran \\ Full list of author information \\ is available at the end of the \\ article
}

\begin{abstract}
The current study compared the effects of two types of flipped instruction (FI) (lowand mid-tech) with two other class conditions, a blended course and a conventional teaching, on learning outcome of language learners with different levels of impulsivity in an on-campus General English (GE) course. To attain such a goal, four GE classes consisting of 100 freshmen (25 students in each class) were selected and organized into 3 experimental (mid-tech Fl, low-tech Fl, blended instruction) and 1 control group (conventional teaching). In low-tech flipped class, the students were provided with the vodcasts and podcasts of the instructor's teaching. For the mid-tech flipped class, the podcasts and vodcasts were integrated into an educational website where all instructional and supplementary materials were available. The blended group accessed the educational website after the instructor's teaching as the extension of the class activities. The control group received the GE conventional instruction (chalk and talk approach). The participants'learning outcome was assessed by reading paper of Preliminary English Test and their level of impulsivity was measured by BIS-11. The quantitative data were analysed by a two-way analysis of variance (ANOVA) and the results revealed a statistically significant difference in reading proficiency of the four groups after the study, in favour of the mid-tech Fl. Moreover, while the type of instruction had no effect on reading proficiency of students with different levels of impulsivity across groups, within group comparisons revealed that only mid-tech group members with different levels of impulsivity benefited equally from the instruction. The results of the qualitative data analysis revealed that the majority of students in both groups had positive attitudes towards the experience, although they expressed their needs for some modifications in teacher role, their own role, and the way the instructional materials are prepared and presented.
\end{abstract}

Keywords: General English, Flipped, Reading, Impulsivity, Technology

\section{Introduction}

The advancement of technological devices and their ubiquitous presence in everyone's life in the twenty-first century has directed the attention of pedagogues and researchers to the advantages of mingling technology-based learning environments with learner-centred approaches to amplify the benefits of both. Flipped classroom is party material in this article are included in the article's Creative Commons licence, unless indicated otherwise in a credit line to the material. If material is not included in the article's Creative Commons licence and your intended use is not permitted by statutory regulation or exceeds the permitted use, you will need to obtain permission directly from the copyright holder. To view a copy of this licence, visit http:// creativecommons.org/licenses/by/4.0/. 
one such approach that claims to establish "a framework that ensures students receive a personalized education tailored to their individual needs" (Bergmann \& Sams, 2012, p. 6) by benefiting from very simple technologies of digital media recording. The idea of flipping a class seems to be superficially very simple: "events that have traditionally taken place inside the classroom now take place outside the classroom and vice versa" (Lage et al., 2000, p. 32). The accumulation of knowledge on flipped classes by the passage of time, however, has shown that neither the definition nor the execution of the flipped classroom is that simple.

The role of technology in flipped instruction (FI) and the way the instructional content is developed and appropriately integrated into the cycle of teaching is one major concern of flipping the course. While simple technologies of recording the teacher's lectures have been prevalently used in prototypical models of FI, the role of technology in FI has sparked controversy among researchers recently (e.g., He et al., 2016). Although a few studies have investigated the integration of different types of technologies into FI (e.g., Hung, 2015, 2017; Jensen et al., 2018), it is relatively unknown if heightening the level of technology complexity in preparing and delivering the instructional content in flipped classes would affect the learning gain.

Another issue that is in need of further attention in FI literature is the way diverse groups of leaners are influenced by inversing the course. The flipped class is claimed to take account of students' problems in learning including poor learning strategies, lack of motivation to learn and lack of interest in certain subjects by personalizing teaching-learning processes and meeting students' individual needs (Bergmann \& Sams, 2012). In spite of this, most studies on FI have vastly focused on general advantages and disadvantages of this approach (Akçayıra \& Akçayırb, 2018) rather than the way people with diverse backgrounds behave when the class is flipped.

A third concern to address in FI research is the huge surge of interest in examining the role of FI in science and engineering classes and the scarcity of research in certain areas such as humanities. Most studies on FI have been done in the context of higher education in Natural sciences and Medical courses (e.g., See \& Conry, 2014; Awidi \& Paynter, 2019; Yilmaz, 2017). In this regard, one particular subject matter that is in need of further consideration in FI research is foreign language teaching and learning as the dynamics of the flipped class, the interaction between students and the teacher, the patterns of collaboration (Mehring, 2018) through social, active and discovery learning, are all in alignment with underpinnings of language teaching and learning. Recently, research on the effectiveness of FI on language learning is booming (e.g., AlHarbi \& Alshumaimeri, 2016; Zarrinabadi \& Ebrahimi, 2019; Zhang et al., 2016) but still empirical evidence to draw firm conclusions about how FI affects language learning is insufficient.

Considering the above-mentioned issues, the current study considers the impact of technology type (low-tech vs. mid-tech) in preparing FI pre-class content on learning gains of learners with different levels of impulsivity in a General English (GE) course in the context of higher education. The goal of this study is threefold:

a. comparing the effects of two prevalent types of flipped classes, the one that uses the instructor's vodcast/podcast (low-tech) and the one that uses an online website with 
pedagogically organized materials (mid-tech) on the development of English reading proficiency;

b. comparing the effects of FI with two other class conditions, that is a blended course and a conventional teaching (chalk and talk approach) on the development of English reading proficiency; and

c. incorporating the participants' levels of impulsivity into the design of the study and comparing the effects of four instructional conditions on the development of their English reading proficiency.

\section{Review of literature}

\section{The role of technology in FI}

One main concern about FI first and foremost arises from the idea of using technology to invert or flip the class. While some researchers believe and empirically supported the fact that technology is not an essential component of flipped classroom (Moravec et al., 2010), some think that the two themes are inextricably interwoven (Bishop \& Verleger, 2013; Lage et al., 2000). A glimpse of the review studies done on flipped classrooms suggests that researchers have shown interest in both ideas and do not seem to consider them as polar opposites. In their review study that examined publications on flipped classes till 2016, Akçayıra and Akçayırb (2018) reported that while a majority of the outof-class content was mainly designed by simple technologies of recorded videos (79\%), reading materials were also used by almost half of the researchers for preparing the outof-class content. Based on this review, very few studies (less than 7\%) have used online modules or interactive software programs in flipped classes. In a recent study, Han and Klein (2019) reported that half of the works published within the science and health profession courses till 2017 benefited from reading assignments as pre-class learning activities in flipped classes and the other half used video lectures or online modules.

As to disagree with the idea of associating the notion of flipped class with technology, He et al. (2016) asserts that "qualifying instructional medium is unnecessary and unjustified" (p. 61) for FI and thus any model that includes an obligatory pre-class learning followed by in-class active learning with mandatory class attendance can be called a flipped class. Mehring (2018) also believes that although technology has made flipping the class easier, what should be the focus in implementing the flipped approach is "a pedagogical change and not a technological one” (p. 1). In agreement with this, Brown (2018) proposes the continuums of course content preparation as high quality versus homemade, personal touch versus a curated blend of sources, simplicity versus an engaging mix of media and formats, and high tech versus low tech (pp. 16-17) in which the role of technology complexity is implied in preparing the materials for the flipped class.

In spite of the continuing controversies over the role of technology in flipped classrooms, the provision of studies which have used solely reading materials for the preclass phase (no-tech content) is not limited. Textbook reading is one of the commonest assignments given to students for the pre-class phase. Other reading materials include guided readings (such as handouts and worksheets) and primary literature (Han \& Klein, 2019). 
Low-tech out-of-class content in flipped classes fundamentally consists of video or audio recordings of the instructor's teachings that can be captured by simple devices such as mobile phones (vodcasts/podcasts) or desktop software (screen-casting/voice over Microsoft PowerPoint presentations) (Crawford \& Senecal, 2017). Due to the fact that the basic definition of a flipped classroom is closely associated with this type of technology that does not demand high IT literacy, the studies that used low-tech materials dominate the literature (Akçayıra \& Akçayırb, 2018). The combination of no- and low-tech contents is also quite prevalent where video lectures are given to students with reading materials as out-of-class activities (e.g., Gilboy et al., 2015).

Mid-tech systems such as online modules can also be used to prepare pre-class activities of a flipped class. These include either ready-made platforms that can be used by teachers for uploading their content or open source systems that can be customized to the needs of the class by programming. Mostly, different types of LMSs like Moodle (Bakla, 2018), Edmodo (Al-Harbi \& Alshumaimeri, 2016), and Blackboard (Fadol et al., 2018) or local LMSs (Yilmaz, 2017) are used to upload the ready-made content (such as the instructor's video recordings, readings, quizzes, assignments, etc.). Some researchers used recorded videos from TED.Ed Talks (Hung, 2017), You Tube (Sengel, 2016), or Khan Academy (Martin et al., 2013) related to the subjects of the lessons. Online lesson plan formats like WebQuest (Hung, 2015) or social media such as LINE (Hsieh et al., 2017) or Telegram (Haghighi et al., 2019) have also been integrated into the pre-class phase due to their ease of use.

Contrary to expectations, a limited percentage of pre-class materials have been produced with high-tech systems or Intelligent Tutoring Systems (ITSs) for the flipped classes (e.g., Mohamed \& Lamia, 2018; Strayer, 2012). Due to the fact that the architecture of ITS consists of essential components such as domain, student, tutoring, and interface models to make the system capable of making smart decisions about tutoring strategies and actions, its development needs sophisticated IT literacy, extended time, and financial resources from the teacher's side and involvement of program developers.

Based on the reviewed studies, a continuum of technology complexity for preparing the out-of-class content of the flipped classroom is deduced (Fig. 1). The continuum is used in the current study to differentiate two FI conditions, that is mid-tech FI from low-tech FI, and compare their effects for reaching the goals of the study. The provided examples are taken from the literature and the list is by no means exhaustive.

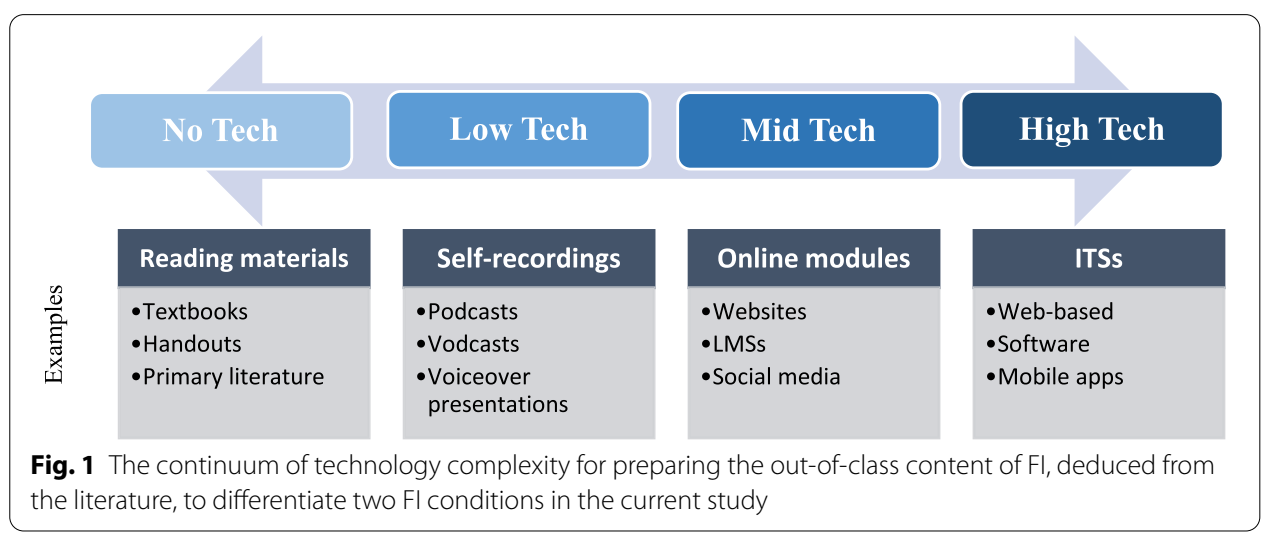


It is also noteworthy to mention that the continuum addresses the technology complexity that has been utilized in FI content preparation with respect to three basic criteria: teacher IT literacy, the need to programing knowledge, and the presence of ITS architecture. As a matter of fact, from low-tech to mid- and high-tech, the need for expected IT literacy of the teacher, programming knowledge, and inclusion of features of ITS architecture in the system becomes absolutely essential.

\section{The role of instructional practices in flipping the class}

The way the teaching content is prepared and delivered to students in FI raises a second concern, that is how the whole class is planned, how the out-of-the class materials are organized coherently and how they are linked to in-class activities. It is believed that "only instructing students to watch a video or read a book outside the class is a recipe for failure in the flipped classroom" (Zainuddin, 2018, p. 76). The main challenges reported in the literature with respect to this issue are students' limited preparation before class, the degree of support and assistance they can get while doing out-of-class activities, their need to guidelines at home, and their increased out-of-class workload (Akçayıra \& Akçayırb, 2018). It is evident that most of the time students do not do pre-class assignments because they are not clearly instructed (Brunsell \& Horejsi, 2013) and they do not know what to do (Çakıroğlu \& Öztürk, 2017). This can be related to teachers' problems in implementing the flipped approach, managing the tasks, and planning the sequences of the activities (Akçayıra \& Akçayırb, 2018). To resolve this issue, recently some studies have combined innovative strategies with the flipped class to increase students' participation in pre-class and in-class activities. Incorporating the elements of games (e.g. scores, points, badges, and leader boards) into FI (Zainuddin, 2018), using in-flip class strategy where out-of-class activities take place in class environment (Fethi \& Marshall, 2018; Ramirez, 2018), and designing the learning activities of the flipped course with reference to the principles of self-regulation $(\mathrm{Ng}, 2018)$ are among such works.

Considering the fact that the flipped class needs "planned instructional strategies" (Shyr \& Chen, 2018, p. 1) and sound pedagogical premises for preparing the content and integrating the instructional materials and activities, a few studies have compared the effects of flipped classes with different types of pre-class and in-class materials or activities. Hung (2015) compared two types of flipped courses called structured and semi-structured with a non-flipped class. The structured flipped class consisted of organized materials in WebQuest and the semi-structured flipped class consisted of videos taken from TED-Ed. The results showed that learners' academic performance of the structured group was higher than the other two groups. In another study, Hung (2017) compared two flipped conditions of in-class interaction (just in time teaching vs. peer interaction) and reported that the peer interaction condition led to better learning, satisfaction with the flipped class, and willingness to communicate among the participants. Jensen et al. (2018) examined three methods of pre-class content learning in three flipped courses, i.e., interactive online tutorials, video lectures, and textbooks readings in a biology course. Their findings showed that video lectures offered a small advantage to overall student learning in comparison to other two content learning strategies. 


\section{$\mathrm{Fl}$ and individual differences}

To address the diversity factor, some studies have focused on the demographic and background differences of the learners to scrutinize the effect of FI on their leaning gains. He et al (2016) assessed the impact of FI on students' out-of-class study time, exam performance, preference, motivation, and perceptions; and observed that students of diverse backgrounds (major, education level, and gender) benefited uniformly from the course. In another study, Hsieh et al. (2017) assessed technology acceptance among EFL learners utilizing a mobile-based flipped class and reported certain differences in the construct relationship among students of different proficiency levels. Bakla (2018), in a study on the effectiveness of student-generated materials in a flipped course, examined the participants' contribution and concerns about creating the content while their digital literacy level was taken into account. Walsh and Rísquez (2020) identified hidden patterns of students' online behaviour in a flipped classroom environment and reported a difference between native and non-native English speakers assuming that language proficiency and cultural background are among the factors to be considered in FI. In a recent study, Strelan et al. (2020) carried out a meta-analysis of the effects of the flipped classes on student performance across disciplines and education levels. The finding suggests that the effect is magnified among secondary students while it remains unchanged in tertiary settings. Also, relatively weak to moderate effects are reported for health sciences, IT, mathematics, business, and medical and physical sciences; while moderately strong to strong effects for engineering, teaching and humanities have been observed.

\section{Fl and learning styles}

Learning style refers to "an individual's preferred way of processing information and of dealing with other people" (Ellis, 2008, p. 535). In this framework, the cognitive style is specifically an individual's preferred approach to representing and organizing information (Riding \& Rayner, 1998). As one of the dichotomies of cognitive style, impulsivity/reflectivity is generally associated with "conceptual tempo which embraces the idea of the time spent on completing a task (Michonska-Stadnik, 2013, p. 138) . Impulsive learners generally make a quick guess to answer a question or solve a problem and lack accuracy. Reflective learners, in contrast, think deeply to solve problems and make more calculated decisions (Brown, 2007).

Some studies have reported that impulsive and reflective language learners have distinct learning preferences such as personal preference for communicative strategies, language learning strategies, and types of classroom interaction (e.g., Soltani et al., 2015). The impact of cognitive styles on students' benefit from computer-assisted language learning environment is also evident (e.g., Chapelle \& Fraiser, 2009).

Although FI has been reported to be an ideal instructional approach to address students' diversity by tailoring the content to their preferred ways of learning, research on the effectiveness of FI on learning performance of students with different learning styles or strategies is rare. In their study, Chen et al. (2014) examined the effectiveness of a flipped course on students' satisfaction of the course, attendance, and study effort and reported that highly motivated students performed much better than less motivated students. Chen et al. (2019) examined the learning gains of students with different cognitive styles in a flipped class and reported that field-independent students had better 
academic achievement in comparison to field-dependent and field-neutral students, particularly in quizzes and the final grades. Goedhart et al. (2019) investigated the experience of FI among students with different learning styles and motivation and reported that the flipped class can address the needs of students with diverse learning needs as it allows students to customise or self-regulate the learning process to their personal needs and learning styles. Alten et al. (2020) replicated the effects of SRL support in a flipped class on learning outcomes and course satisfaction and suggested that students' benefit from a flipped course may depend on their self-regulatory leaning skills and this should be considered in designing the flipped course content.

\section{$\mathrm{Fl}$ and foreign language learning}

Studies on foreign language learning and FI generally focus on two main themes including attitudes towards the flipped approach and the benefit of language learners from the flipped class in teaching language micro and macro skills. The attitudes of language learners towards FI have been assessed in grammar (e.g., Al-Harbi \& Alshumaimeri, 2016; Kheirabadi, 2017), conversation (e.g., Warden, 2016) and pronunciation (e.g., Bakla, 2018) courses. Also, the attitudes of English Language Teaching (ELT) professors and students have been examined towards integrating the flipped approach into undergraduate courses (e.g., Vaezi et al., 2019). The impact of FI on learning outcomes has also been assessed in teaching vocabulary (Zhang et al., 2016), listening and speaking (Amiryousefi, 2019), and communication skills (Haghighi et al., 2019; Zarrinabadi \& Ebrahimi, 2019).

Most studies in this framework have focused on oral skills and written skills have been examined in a very few studies (e.g. Brown, 2018; Buitrago \& Díaz, 2018). More particularly, General English and English for Specific Purposes (ESP) courses in higher education have not been focused on in FI literature. Both instructors and learners face lots of challenges in these courses including too much materials to be covered especially long lists of new words and grammatical structures and long passages, lack of enough time, large classes, and students with multiple proficiency and diverse needs (Phuong, 2002). Based on the theoretical underpinnings of FI, it can be deduced that those activities that take time and require lower-order cognitive processing can be transferred to the outof-class phase and thus the class time can be spent on higher-order cognitive activities through deepening understanding and promoting learning efficiency that can give better time management to language instructors (Bergmann \& Sams, 2012; Lage et al., 2000).

\section{Method}

Participants

One hundred freshmen enrolled in GE courses in a private university in Tehran in Fall 2018-2019 participated in the study. GE is one of the compulsory courses freshmen should take in their first semester based on the syllabus of BS majors. The freshmen are qualified to enrol in GE course if they have answered at least 30\% of the questions of English exam correctly in National University Exams (known as Konkoor).

Eight classes of GE were available, out of which 4 classes were randomly selected and assigned into three experimental and one control group to fulfil the conditions of the current study. The sample included both male $(\mathrm{n}=42,42 \%)$ and female $(\mathrm{n}=58,58 \%)$ 
Table 1 The participants of the study and their class condition

\begin{tabular}{|c|c|c|c|c|c|}
\hline \multirow[t]{2}{*}{ Groups } & \multicolumn{3}{|l|}{ Number } & \multirow[t]{2}{*}{ Instructional content } & \multirow{2}{*}{$\begin{array}{l}\text { Condition of the } \\
\text { instruction }\end{array}$} \\
\hline & Female & Male & Total & & \\
\hline $\begin{array}{l}\text { Experimental group one: } \\
\text { mid-tech FI }\end{array}$ & 13 & 12 & 25 & $\begin{array}{l}\text { The instructional materials } \\
\text { delivered via a website }\end{array}$ & $\mathrm{Fl}$ \\
\hline $\begin{array}{l}\text { Experimental group two: } \\
\text { low-tech FI }\end{array}$ & 8 & 17 & 25 & $\begin{array}{l}\text { The audio/video recorded } \\
\text { lectures }\end{array}$ & $\mathrm{Fl}$ \\
\hline $\begin{array}{l}\text { Experimental group three: } \\
\text { the blended course }\end{array}$ & 20 & 5 & 25 & $\begin{array}{l}\text { The designed website as } \\
\text { the blend of in-class } \\
\text { instruction }\end{array}$ & blended instruction \\
\hline $\begin{array}{l}\text { Control group: the conven- } \\
\text { tional teaching }\end{array}$ & 17 & 8 & 25 & $\begin{array}{l}\text { The textbook and regular } \\
\text { homework }\end{array}$ & $\begin{array}{l}\text { chalk-and-talk teaching } \\
\text { techniques }\end{array}$ \\
\hline
\end{tabular}

Table 2 Can do lists of B1 level reflected in B1 Preliminary reading paper (Cambridge English Qualifications, 2020, p. 6)

\begin{tabular}{ll}
\hline Typical abilities & Reading \\
\hline $\begin{array}{l}\text { Overall general ability } \\
\text { Social and tourist }\end{array}$ & CAN understand routine information and articles \\
Work & CAN understand factual articles in newspapers, routine letters from hotels \\
and letters expressing personal opinions & CAN understand the general meaning of non-routine letters and theoreti- \\
Cal articles within own work area
\end{tabular}

students that ranged in age between 18 and 28 years old. All students were Iranian by nationality and English was a foreign language for them. They had already studied English in compulsory education for 6 years before entering the university.

The groups, the number of their participants and the conditions of the instruction they received are depicted in Table 1.

\section{Instruments}

\section{B1 Preliminary}

The goal of teaching GE is improving students' reading proficiency to prepare them to read academic English texts extensively. To assess the participants' reading proficiency prior and after the study, reading paper of B1 Preliminary was used. B1 Preliminary is a test among Cambridge English Qualifications, a group of examinations developed by Cambridge ESOL at Cambridge University. There are seven tests from pre A1 to C2 clustered in three proficiency levels (basic, independent, proficient) based on Common European Framework of Reference (CEFR). B1 Preliminary is the first test of level 'independent' and assesses candidates' proficiency of basics of English and practical language skills for everyday use.

B1 Preliminary is made up of four papers including reading, writing, listening, and speaking. For the purpose of this study, the reading paper was used. This paper has 6 parts and 32 questions. Typical reading abilities of B1 level based on the Association of Language Testers in Europe's (ALTE) Can Do statements are summarized in Table 2 (Cambridge English Qualifications, 2020). 
The reliability of B1 Preliminary was estimated by KR-21 and found to be 0.70 and 0.86 for pre-test and post-test respectively.

BIS-11

To assess the participants' level of impulsivity, Barratt impulsive scale (BIS-11) was used. BIS-11 is a widely used measure of impulsiveness and consists of 30 self-report items. The scale has six first-order factors including: attention ( 5 items), motor ( 7 items), selfcontrol (6 items), cognitive complexity (5 items), perseverance (4 items), and cognitive instability (3 items).

The scale is anchored on a four-point Likert scale: $1=$ rarely/ never, $2=$ occasionally, $3=$ often, and $4=$ almost always/always. Based on Knyazev and Slobodskaya's (2006) scoring scheme, the total score of 72 or above is considered as very highly impulsive, the scores between 52 and 71 as the normal limits of impulsiveness, and below 52 over-controlled.

The reliability of the questionnaire has been reported to be from 0.79 (Patton et al., 1995) to 0.83 (Stanford et al., 2009) in the literature. The scale has been translated and validated in Persian and its reliability has been reported to be from 0.60 to 0.83 . BIS-11 is viewed as a more valid and practical scale to measure the degree of impulsivity-reflectivity of Iranians in comparison to other scales (Arianakia \& Hassani, 2014; Ekhtiari et al., 2008).

\section{Open-ended questionnaire}

In order to assess the participants' attitudes towards FI, all members of the experimental groups 1 and 2 were asked to answer an open-ended questionnaire. 37 students (21 participants from the mid-tech FI and 16 participants from the low-tech FI) filled in the questionnaire. The questionnaire had 9 questions regarding the instruction they received in terms of four themes:

- Students' perceptions of FI (2 questions)

- Teacher role in FI (2 questions)

- Challenges and opportunities of FI (3 questions)

- Learning outcome of FI (2 questions)

The main themes of the open-ended questionnaire were developed based on merits and demerits of FI reported in the literature (e.g., Akçayıra \& Akçayırb, 2018). Twelve questions were written by the researchers by reviewing the published works. The questions were reviewed by two researchers who had worked on FI previously. Some modifications were done in the wording and number of items based on their suggestions and thus 9 questions were finally used to gather the qualitative data.

\section{Teaching materials}

\section{The textbook}

All four groups studied the same textbook for their GE course, Revive your General English (Kasikhan, 2016). The book has thirteen lessons and each lesson has three main parts including reading passages, grammatical structures, and new words. 


\section{Instructional materials for the flipped classes}

Audio and video recordings of the teachings were prepared by the instructor for the flipped classes. Fifteen video/audio recordings with an average length of $10 \mathrm{~min}$ were prepared. These recordings were the essential instructional content for the low-tech flipped class.

For the mid-tech flipped class, additional materials were prepared and integrated into an educational website designed for this study. To make the materials for flipped classes, Brown's (2018) guideline was considered. The comparison between the teaching materials of the two flipped classes is shown in Table 3.

\section{The website}

A freestanding educational website was designed to deliver created and curated instructional materials for the experimental group 1 (the mid-tech flipped class) and to function as the blend of the in-class teaching for the experimental group 3 (the blended course). It was hosted by gigfa.com for 6 months free of charge and was both desktopand mobile-based. The website had the following sections: created podcasts/vodcasts, reading materials (both intensive and extensive readings), useful links to extra resources (online dictionaries, multimedia, etc.), slideshows, list of new words and their meanings, explanations of grammatical structures, extra exercises, quizzes, and task sheets.

Table 3 Instructional materials for the flipped classes (based on Brown, 2018)

\begin{tabular}{|c|c|c|c|}
\hline Criteria & Continuums & Low-tech FI & Mid-tech FI \\
\hline \multirow[t]{4}{*}{ Sources } & High quality versus homemade & Homemade & Rather high quality \\
\hline & $\begin{array}{l}\text { Teachers' personal touch and } \\
\text { presence in students' out-of- } \\
\text { classroom experience versus a } \\
\text { curated blend of sources }\end{array}$ & Personal touch & $\begin{array}{l}\text { Both personal } \\
\text { touch and } \\
\text { curated }\end{array}$ \\
\hline & $\begin{array}{l}\text { Consistency and simplicity ver- } \\
\text { sus an engaging mix of media } \\
\text { and formats }\end{array}$ & Consistency and simplicity & Mix of media \\
\hline & High tech versus low tech & Low tech & Mid tech \\
\hline \multirow[t]{5}{*}{ Video recordings } & Talking head video & $\checkmark$ & $\checkmark$ \\
\hline & $\begin{array}{l}\text { Talking-head-style but with } \\
\text { instructor writing on a white- } \\
\text { board }\end{array}$ & $\checkmark$ & $\checkmark$ \\
\hline & $\begin{array}{l}\text { Talking-head-style but with } \\
\text { instructor seated at a desk }\end{array}$ & $\checkmark$ & $\checkmark$ \\
\hline & $\begin{array}{l}\text { Talking-head-style but with } \\
\text { instructor in conversation } \\
\text { with colleague or another } \\
\text { professional }\end{array}$ & - & - \\
\hline & $\begin{array}{l}\text { Demo of an activity in appropri- } \\
\text { ate setting }\end{array}$ & - & - \\
\hline \multirow[t]{2}{*}{ Supportive tools and formats } & $\begin{array}{l}\text { Interactive learning objects } \\
\text { built with specialized software }\end{array}$ & - & $\checkmark$ \\
\hline & $\begin{array}{l}\text { Text-based options (books, } \\
\text { eBooks, pdf files, quizzes) }\end{array}$ & - & $\checkmark$ \\
\hline \multirow[t]{3}{*}{ Platform } & A freestanding website & - & $\checkmark$ \\
\hline & An LMS & - & - \\
\hline & Single-point access & $\checkmark$ & - \\
\hline
\end{tabular}




\section{Procedure}

The study took place in Fall semester of the academic year 2018-2019 for 16 weeks. The students attended the classes once a week and each session lasted for 150 min (two 75-min sessions with a 10-min interval break). All participants took part in the pre-test and their entry level of reading proficiency was checked prior to the study. The students of the experimental groups were then introduced to FI, how it was going to be implemented by the instructor, what they were expected to do, and the technologies they needed for the course. The procedure of teaching in each group is explained below:

Mid-tech flipped class: The instruction was based on the flipped approach consisting of two phases: pre-class and in-class. The pre-class teaching content included both curated and created teaching materials delivered via the designed website. A summary of the class procedure for one session is summarized in Table 4.

Low-tech flipped class: The low-tech flipped class also received instruction based on the flipped approach while the pre-class activities included just the created vodcasts and podcasts. The students were asked to watch the vodcasts or listen to the podcasts and do as the teacher instructed them in the pre-class phase.

It should be noted that the class procedures for both mid-tech and low-tech FIs were the same. The main difference between the two instructions lies in the way the pre-class

Table 4 A sample lesson plan for mid-tech FI

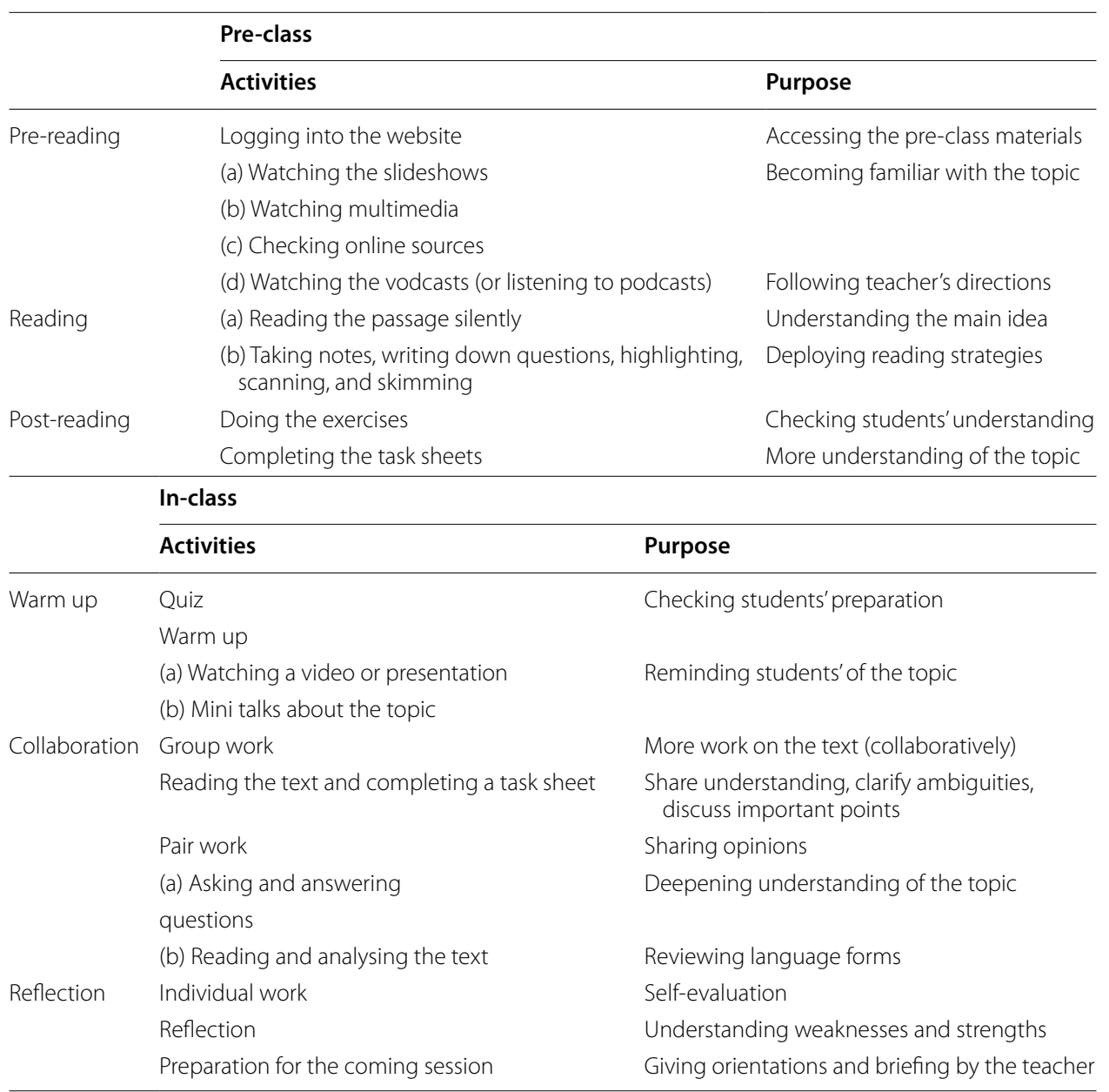


Table 5 The result of ANOVA on B1 Preliminary pre-test scores

\begin{tabular}{lcllll}
\hline & Sum of squares & Df & Mean square & F & Sig \\
\hline Between groups & 82.611 & 3 & 27.537 & 1.340 & 0.266 \\
Within groups & 1973.173 & 96 & 20.554 & & \\
Total & 2055.785 & 99 & & & \\
\hline
\end{tabular}

Table 6 Tests of between-subjects effects

\begin{tabular}{|c|c|c|c|c|c|c|}
\hline Source & $\begin{array}{l}\text { Type III sum of } \\
\text { squares }\end{array}$ & Df & Mean square & $\mathrm{F}$ & Sig & $\begin{array}{l}\text { Partial } \\
\text { Eta } \\
\text { squared }\end{array}$ \\
\hline Corrected model & 1080.950 & 11 & 98.268 & 2.453 & 0.010 & 0.235 \\
\hline Intercept & $51,234.283$ & 1 & $51,234.283$ & 1279.109 & 0.000 & 0.936 \\
\hline Group & 792.451 & 3 & 264.150 & 6.595 & $0.000 *$ & 0.184 \\
\hline Impulsivity & 7.616 & 2 & 3.808 & 0.095 & 0.909 & 0.002 \\
\hline Group * impulsivity & 239.165 & 6 & 39.861 & 0.995 & 0.434 & 0.064 \\
\hline Error & 3524.810 & 88 & 40.055 & & & \\
\hline Total & $58,988.000$ & 100 & & & & \\
\hline Corrected total & 4605.760 & 99 & & & & \\
\hline
\end{tabular}

materials were prepared and delivered to students (audio/video files vs. a freestanding website).

The blended course: The blended class was based on a supplemental blended model, where the online content was used to enrich the face-to-face classroom teaching. No reduction in classroom meeting time was done while the students were expected to do certain types of activities by referring to the website to extend the learning out of the class. This group used the same website designed for the mid-tech flipped course.

Conventional teaching: The instruction was delivered through chalk-and-talk teaching techniques in this group. No specific technology was used to teach the content.

At the end of the course, all four groups participated in the post-test.

\section{Data analysis}

\section{Pre-test}

Before the study, the entry-level reading proficiency of the participants was examined by reading paper of B1 Preliminary. A one-way analysis of variance (ANOVA) was used to check the homogeneity of the groups' reading proficiency prior to the study (Table 5).

As Table 5 shows, the result of ANOVA indicates that there was no significant difference between the four groups' reading proficiency prior to the study $(\mathrm{F}=1.340$, $p=0.266<0.05)$.

\section{Quantitative data analysis}

In order to examine the participants' development of reading proficiency after the study, a two-way analysis of variance (ANOVA) was conducted. In this analysis, B1 Preliminary served as the dependent variable and type of instruction (4 levels: mid-tech FI, low-tech FI, blended course, and conventional teaching) and impulsivity (3 levels: high, normal, low) were the independent variables. The results for the first main effect (type of 
Table 7 Multiple comparisons (Tukey HSD)

\begin{tabular}{llllllc}
\hline (I) group & (J) group & $\begin{array}{l}\text { Mean difference } \\
(\mathbf{I}-\mathbf{J})\end{array}$ & Std. error & Sig & \multicolumn{2}{c}{$\mathbf{9 5 \% \text { Confidence Interval }}$} \\
\cline { 6 - 7 } & & & & & Lower bound & Upper bound \\
\hline Mid-tech FI & Low-tech FI & $5.600^{*}$ & 1.790 & 0.013 & 0.912 & 10.287 \\
& Blended course & $4.840^{*}$ & 1.790 & 0.040 & 0.152 & 9.527 \\
& Control group & $7.960^{*}$ & 1.790 & 0.000 & 3.272 & 12.647 \\
\multirow{2}{*}{ Low-tech FI } & Blended course & 0.7600 & 1.790 & 0.974 & -3.927 & 5.447 \\
& Control group & -2.360 & 1.790 & 0.554 & -7.047 & 2.327 \\
Control group & Blended & -3.120 & 1.790 & 0.308 & -7.807 & 1.567 \\
\hline
\end{tabular}

Table 8 Descriptive statistics of B1 Preliminary across four groups

\begin{tabular}{|c|c|c|c|c|c|}
\hline \multicolumn{2}{|l|}{ Groups } & \multicolumn{2}{|c|}{ Pre-test } & \multicolumn{2}{|c|}{ Post-test } \\
\hline & & $M$ & SD & $M$ & SD \\
\hline \multirow[t]{4}{*}{ Mid-tech FI } & Total & 10.840 & 4.412 & 27.920 & 3.463 \\
\hline & $\mathrm{HI}$ & 9.000 & 3.464 & 27.750 & 2.052 \\
\hline & $\mathrm{Ml}$ & 13.000 & 6.260 & 28.000 & 4.898 \\
\hline & LI & 11.000 & 3.633 & 28.000 & 3.714 \\
\hline \multirow[t]{4}{*}{ Low-tech FI } & Total & 12.280 & 4.578 & 22.320 & 8.204 \\
\hline & $\mathrm{HI}$ & 11.416 & 4.981 & 20.250 & 7.569 \\
\hline & Ml & 11.333 & 3.559 & 23.666 & 8.164 \\
\hline & LI & 14.571 & 4.391 & 24.714 & 9.569 \\
\hline \multirow[t]{4}{*}{ Blended course } & Total & 12.666 & 4.099 & 23.080 & 6.356 \\
\hline & $\mathrm{HI}$ & 15.000 & 4.000 & 26.000 & 2.280 \\
\hline & $\mathrm{Ml}$ & 12.333 & 4.438 & 22.923 & 6.460 \\
\hline & LI & 11.000 & 3.346 & 20.500 & 8.384 \\
\hline \multirow[t]{4}{*}{ Control group } & Total & 13.320 & 4.997 & 19.960 & 6.106 \\
\hline & $\mathrm{HI}$ & 15.444 & 6.247 & 21.333 & 6.670 \\
\hline & $\mathrm{Ml}$ & 11.375 & 2.263 & 18.000 & 5.070 \\
\hline & LI & 12.875 & 5.055 & 20.375 & 6.653 \\
\hline
\end{tabular}

HI high impulsive, $M I$ moderate impulsive, $L /$ low impulsive (reflective)

intervention) suggested that there was a statistically significant difference among posttest scores of the four groups $(\mathrm{F}=6.595 ; p=0.000<0.05$; partial eta squared $=0.184)$ (Table 6).

The Tukey post-hoc test (Table 7) and descriptive statistics (Table 8) showed that the mid-tech flipped class had the best performance among the four groups (Mean $=27.92$, $\mathrm{SD}=3.46)$ and was the superior method to teach reading comprehension in the GE courses.

Investigating the second main effect showed that there was no statistically significant difference between the performance of students with different levels of impulsivity $(\mathrm{F}=095 ; p=0.909>0.05$; partial eta squared $=0.002)$ in these four courses. In spite of this, the profile plot (Fig. 2) was used to visually inspect the relationship among the variables and examine the performance of students with different levels of impulsivity in B1 Preliminary post-test across the groups.

As Fig. 2 shows, students of the mid-tech flipped class with different levels of impulsivity performed roughly at the same level in B1 Preliminary post-test, meaning 


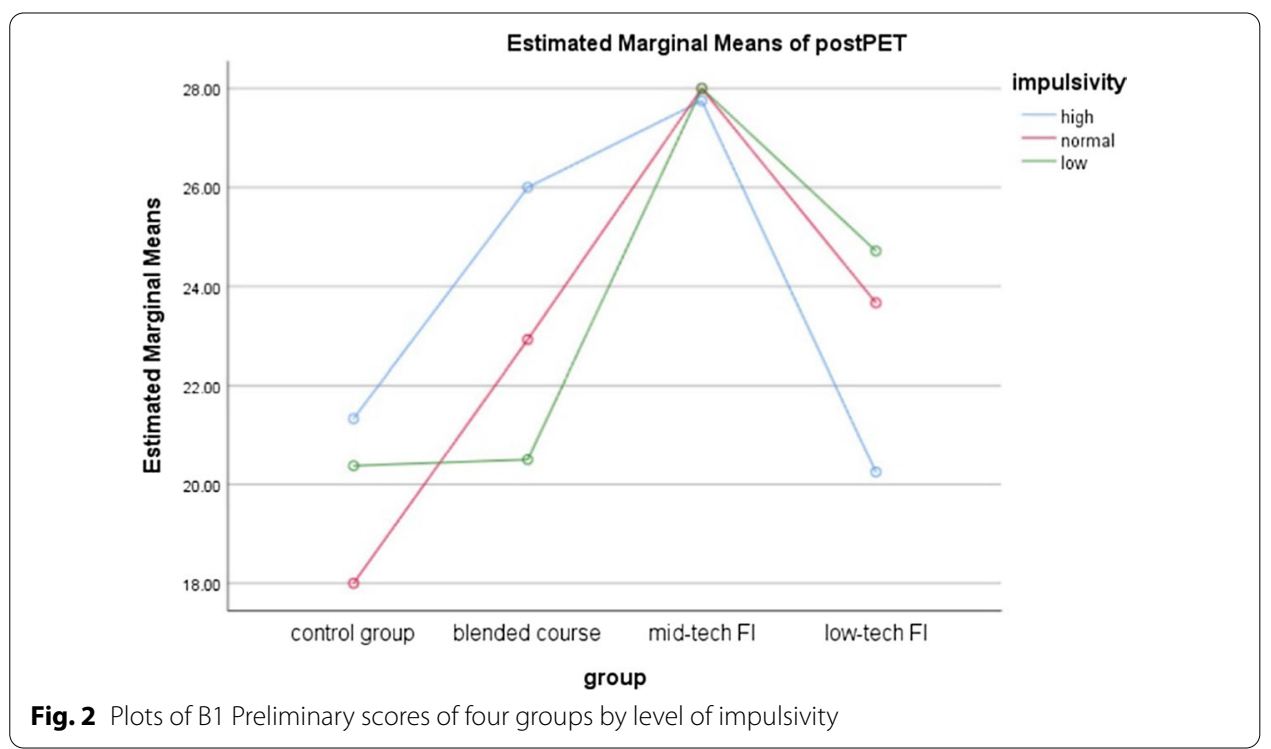

that mid-tech FI can prepare the ground for developing the reading proficiency of all three groups from over-controlled, to normal and highly impulsive. The condition is a little bit different while low-tech FI is considered. As it is shown in Fig. 2, over-controlled students had a better performance in low-tech flipped class (Mean $=24.714$, $\mathrm{SD}=9.56)$, followed by normal (Mean $=23.666, \mathrm{SD}=8.164)$ and high impulsive (Mean $=20.25, \mathrm{SD}=7.569)$ students; while this is reversed in the blended course, where high impulsive participants (Mean $=26.0, \mathrm{SD}=2.28$ ) had better performance in B1 Preliminary in comparison to low (Mean $=20.50, \mathrm{SD}=8.384$ ) and normal impulsive (Mean $=22.923, \mathrm{SD}=6.46)$ participants.

Finally, it was observed that the 2-way interaction between type of intervention and the participants' level of impulsivity was not statistically significant $(F=0.995$; $p=0.434>0.05$; partial eta squared $=0.064$ ).

\section{Qualitative data analysis}

In order to examine the participants' attitudes towards FI, qualitative analysis of the answers of mid-tech and low-tech flipped classes to the open-ended questionnaire was done. NVivo 12 Pro was used to reduce the qualitative data and come up with categories that address different dimensions of the participants' attitudes. A hierarchy of codes, sub-themes, and themes were established based on the relationships between codes, frequencies of codes, and the underlying meanings across codes (Saldana, 2015) using the software output (Table 9). Following that, the qualitative data were interpreted and conclusions were drawn.

Challenges and opportunities: Students held both negative and positive attitudes towards FI and gave some suggestions for improving the course based on their experience. The negative points mostly mentioned by the students were related to (a) the use of English as the medium of instruction, (b) the load of teaching materials, and (c) technological aspects of the course (Table 10). 
Table 9 Themes and subthemes

\begin{tabular}{|c|c|c|c|c|c|c|}
\hline Themes & Rank & Word & Count & $\begin{array}{l}\text { Weighted } \\
\text { percentage } \\
(\%)\end{array}$ & Subthemes & Meaning \\
\hline \multirow{5}{*}{$\begin{array}{l}\text { Challenges/oppor- } \\
\text { tunities }\end{array}$} & 1 & Teacher & 22 & 4.40 & \multirow{5}{*}{$\begin{array}{l}\text { Advantages } \\
\text { Disadvantages }\end{array}$} & \multirow{5}{*}{$\begin{array}{l}\text { Negative and positive } \\
\text { attitudes towards FI }\end{array}$} \\
\hline & 2 & Students & 15 & 3.00 & & \\
\hline & 3 & Videos & 14 & 2.80 & & \\
\hline & 4 & Persian & 13 & 2.60 & & \\
\hline & 5 & Class & 12 & 2.40 & & \\
\hline \multirow[t]{5}{*}{ Learning outcomes } & 1 & Materials & 14 & 6.83 & \multirow{5}{*}{$\begin{array}{l}\text { The importance of } \\
\text { the content } \\
\text { The importance of } \\
\text { concentration }\end{array}$} & \multirow{5}{*}{$\begin{array}{l}\text { How Fl helped learn- } \\
\text { ing }\end{array}$} \\
\hline & 2 & Time & 11 & 5.37 & & \\
\hline & 3 & Watch & 11 & 5.37 & & \\
\hline & 4 & Videos & 10 & 4.88 & & \\
\hline & 5 & Period & 14 & 6.83 & & \\
\hline \multirow[t]{5}{*}{ Students'feelings } & 1 & Good & 15 & 8.02 & \multirow{5}{*}{$\begin{array}{l}\text { Positive } \\
\text { Negative }\end{array}$} & \multirow{5}{*}{$\begin{array}{l}\text { Students' feelings } \\
\text { towards/ impres- } \\
\text { sions of the FI }\end{array}$} \\
\hline & 2 & Think & 8 & 4.28 & & \\
\hline & 3 & Strategy & 7 & 3.74 & & \\
\hline & 4 & Happy & 6 & 3.21 & & \\
\hline & 5 & Interaction & 6 & 3.21 & & \\
\hline \multirow[t]{5}{*}{ Teacher role } & 1 & Teacher & 25 & 7.96 & \multirow{5}{*}{$\begin{array}{l}\text { Content/activities } \\
\text { Teaching techniques }\end{array}$} & \multirow{5}{*}{$\begin{array}{l}\text { Expectations from the } \\
\text { teacher }\end{array}$} \\
\hline & 2 & Videos & 16 & 5.10 & & \\
\hline & 3 & Students & 14 & 4.46 & & \\
\hline & 4 & Points & 11 & 3.50 & & \\
\hline & 5 & Class & 10 & 3.18 & & \\
\hline
\end{tabular}

When the students' attitudes in mid-tech and low-tech flipped classes were compared, some differences could be traced in subtheme 'workload' and 'technological issues'. The mid-tech group members believed that the volume of work was too much, but the lowtech group members thought of the cognitive load of the materials as the disadvantages of the flipped class (e.g., ambiguity, difficulty). Further, in examining their views towards the technological issues, it can be seen that the mid-tech group was concerned about the speed of the Internet, while the low-tech group members were concerned about the quality of the files.

The majority of students believed that the flipped class was a very good strategy for teaching GE. The positive attitudes they had were mostly related to (a) the benefits of being able to study English whenever and wherever, (b) having a private English teacher, and (c) the way this approach helped them learn English better and gain higher scores.

Learning outcomes: The students generally believed that the flipped class can have a significant impact on their learning if they study hard. They mentioned some points about the role of the instructional materials of the FI in their learning and how they had to use them to promote their learning differently from their previous style of studying. They particularly addressed two aspects in this theme: (a) the importance of the content, and (b) the importance of concentration while using the materials (Table 11).

Looking into the answers of the students in two FI conditions shows that the midtech group attributed their learning to the role of the content in activating their schemata as well as the role of the package of the instructional materials the teacher had prepared for them. Low-tech group members, however, overemphasized the value 
Table 10 Challenges and opportunities of $\mathrm{Fl}$

\begin{tabular}{|c|c|c|}
\hline Subtheme & Group & Example quote \\
\hline \multicolumn{3}{|l|}{ Disadvantages } \\
\hline \multirow[t]{2}{*}{ The medium of instruction } & MT-FI & $\begin{array}{l}\text { "One of the weak points of the flipped classroom was that my teacher just } \\
\text { talked in English" } \\
\text { "All the materials were excellent but lack of teaching in Persian was one of } \\
\text { its problems" }\end{array}$ \\
\hline & LT-FI & $\begin{array}{l}\text { "The teacher should at the end of each lesson explain the grammatical } \\
\text { points in Persian." } \\
\text { "It is really good. But the inclusion of Persian in teaching should not be } \\
\text { forgotten" }\end{array}$ \\
\hline \multirow[t]{2}{*}{ Workload } & MT-FI & $\begin{array}{l}\text { "The amount of teaching is too much" } \\
\text { "If the amount of course materials was less, the students could have } \\
\text { learned them better." }\end{array}$ \\
\hline & LT-FI & $\begin{array}{l}\text { "There are some ambiguous parts in the videos, that should be explained } \\
\text { by the teacher before the class" } \\
\text { "Some exercises are really difficult to do" }\end{array}$ \\
\hline \multirow[t]{2}{*}{ Technological issues } & MT-FI & $\begin{array}{l}\text { "The students need to increase the speed of their Internet" } \\
\text { "For a course like this, we need better Internet connection." }\end{array}$ \\
\hline & LT-FI & $\begin{array}{l}\text { "In some files, the teacher's voice was low" } \\
\text { "The quality of the videos should improve" }\end{array}$ \\
\hline \multicolumn{3}{|l|}{ Advantages } \\
\hline \multirow[t]{2}{*}{ On-the-go learning } & MT-FI & $\begin{array}{l}\text { "It is very useful due to the fact that we can use it any time and in any con- } \\
\text { dition, even when we are on the way to go to the university, party, etc." }\end{array}$ \\
\hline & LT-FI & $\begin{array}{l}\text { "The good point is that you can repeatedly listen to the audio files even } \\
\text { when you are driving" } \\
\text { "The students can watch the videos and listen to the voices at any time." }\end{array}$ \\
\hline \multirow[t]{2}{*}{ English private teacher } & MT-FI & "I thought I had a private teacher" \\
\hline & LT-FI & $\begin{array}{l}\text { "Flipped classroom was a good idea due to the fact that we could use it at } \\
\text { home and it was like a private teacher." }\end{array}$ \\
\hline \multirow[t]{2}{*}{ Achievement } & MT-FI & $\begin{array}{l}\text { "Applying the flipped classroom strategy can improve our learning." } \\
\text { "It is an excellent class, we can learn better by using the materials." }\end{array}$ \\
\hline & LT-FI & $\begin{array}{l}\text { "It is good. If students use this type of class, they will get twenty." } \\
\text { "The students can learn the materials easily; and by means of a little try } \\
\text { they can get a good grade" }\end{array}$ \\
\hline
\end{tabular}

MT-FI mid-tech flipped instruction, LT-Fl low-tech flipped instruction

of the audios and videos to be repeatedly listened to and watched for learning and reviewing the content. Both groups believed that they had to be very attentive to outof-class and in-class materials to be able to learn better.

Students' feelings: Most students had positive impressions of this approach and felt that they were teaching themselves. They used positive adjectives (such as excellent, good, happy, satisfied, interesting) to either describe their own feelings or the flipped class. However, a few of low-tech group members had negative feelings towards the course, as they had not experienced such a course before. Interestingly, the mid-tech group members had just positive feelings about the instruction (Table 12).

Teacher role: The students generally expected the instructor to (a) improve the instructional content and activities, and (b) apply different types of teaching techniques to encourage them to work on in-class and out-of-class activities (Table 13).

Both groups expected to have more oral activities in the class. While a few mid-tech group members asked for the improvement of the design interface of the website, low-tech group members asked for using other technologies to produce the content. 
Table 11 Learning outcomes of Fl

\begin{tabular}{|c|c|c|}
\hline Subtheme & Group & Example quote \\
\hline \multicolumn{3}{|c|}{ The importance of the content } \\
\hline & MT-FI & $\begin{array}{l}\text { "It was a good class due to the fact that when you watch the videos } \\
\text { prior to the class, you are familiar with the topics that are going to be } \\
\text { discussed in class next session." } \\
\text { "If the students want to learn, they have to use all the materials the } \\
\text { teacher has provided" }\end{array}$ \\
\hline & LT-FI & $\begin{array}{l}\text { "In order to learn the materials, the students should watch the videos } \\
\text { twice." } \\
\text { "I watched the materials several times, so that they remain in my mind } \\
\text { longer." }\end{array}$ \\
\hline \multicolumn{3}{|c|}{ The importance of concentration } \\
\hline & MT-FI & $\begin{array}{l}\text { "Language learners should pay attention to the materials in great } \\
\text { depth. They should not disregard the course content and materials." } \\
\text { "We have to pay attention to the flipped class to be able to do the } \\
\text { exercises." }\end{array}$ \\
\hline & LT-FI & $\begin{array}{l}\text { "We should take note and we should be very attentive." } \\
\text { "The students should pay more attention to the course contents, in } \\
\text { comparison to other courses." } \\
\text { "Concentration on watching films and videos is a must. During our } \\
\text { watching and listening we should not speak to anyone" }\end{array}$ \\
\hline
\end{tabular}

Table 12 Students'feelings towards FI

\begin{tabular}{|c|c|c|}
\hline Subtheme & Group & Example quote \\
\hline \multicolumn{3}{|l|}{ Positive } \\
\hline & MT-FI & $\begin{array}{l}\text { "Flipped classroom strategy was good since it enforces us to pay more attention and give } \\
\text { more importance to our lessons" } \\
\text { "It was an excellent and effective class." }\end{array}$ \\
\hline & LT-FI & $\begin{array}{l}\text { "I can be absent as I have the course materials" } \\
\text { "It was a good and an interesting strategy; especially when we cannot be present and we } \\
\text { don't understand the lesson, we can refer to these videos in order to understand the } \\
\text { course materials better" }\end{array}$ \\
\hline \multicolumn{3}{|l|}{ Negative } \\
\hline & MT-FI & - \\
\hline & LT-FI & $\begin{array}{l}\text { "I became stressful since I did not have the experience of attending a flipped classroom" } \\
\text { "It was bad since I did not have any information about this strategy." }\end{array}$ \\
\hline
\end{tabular}

Table 13 Teacher role in FI

\begin{tabular}{|c|c|c|}
\hline Subtheme & Group & Example quote \\
\hline \multicolumn{3}{|c|}{ Content/activities } \\
\hline & MT-FI & $\begin{array}{l}\text { "The teacher should increase speaking activities in the class." } \\
\text { "The website should be designed in a way that students can access all materials } \\
\text { more easily." }\end{array}$ \\
\hline & LT-FI & $\begin{array}{l}\text { "Each session the teacher should choose some students to lecture the new lesson." } \\
\text { "Other materials such as PowerPoint should be used." }\end{array}$ \\
\hline \multicolumn{3}{|c|}{ Teaching style } \\
\hline & MT-FI & $\begin{array}{l}\text { "The teacher should explain the materials more in the class." } \\
\text { "We learn better if the teacher explains the course materials in both English and } \\
\text { Persian." }\end{array}$ \\
\hline & LT-FI & $\begin{array}{l}\text { "The teacher should write the summary of grammatical points on the board" } \\
\text { "The teacher should not speak fast" }\end{array}$ \\
\hline
\end{tabular}


They also believed that the teacher should improve her teaching style and behaviour while doing in-class activities.

\section{Discussion}

Quantitative data analysis

\section{Effects of mid-tech FI on reading proficiency}

The results of the quantitative data analysis showed that the mid-tech flipped group outperformed the other three groups (low-tech FI, the blended course, and the conventional teaching) in the post-test; and mid-tech FI was found to be an advantageous teaching strategy for improving reading skills and comprehension in a GE course.

This finding first and foremost indicates that the mid-tech FI could address the problems of students and instructors in GE classes such as workload, time management, and student-teacher interactions. Content preparation and delivery with the help of technology based on mid-tech FI gave students the opportunity to benefit from richer instructional materials in the pre-class phase and also assisted their learning by enhancing their interaction with the content, students, and the teacher during the class phase. This has certain benefits for the instructors as well, as they have more time during the class time to focus on students' learning problems and answer their questions. The finding highlights the fact that while both mid- and low- tech FIs merit the advantages of flipping or reversing the instruction, it is the mid-tech FI that can address the needs of both teachers and students more appropriately in GE classes.

The mid-tech FI exploited different types of technologies for content preparation and delivery. Utilizing multimedia, hypertext, hyperlink, and extensive reading materials intermingled FI and computer-based instruction, adding more value to a conventional flipped course and supplying a computer-assisted instruction with a sound instructional approach. This surely helped language learners benefit from the advantages of both approaches that include higher learning achievement, self-directed learning, and meeting individual preferences. In this way the efficiency of FI was improved and its negative effects decreased as one of the disadvantages of conventional flipped classes mentioned in the literature is that just giving the audio or video lectures to students does not necessarily make the course attractive for students and lack of extra materials is one source of demotivation among students who took part in flipped courses (Akçayıra \& Akçayırb, 2018).

It should also be noted that mid-tech FI speaks the language of today's students and lets them learn by the language of technology they know well (Bergmann \& Sams, 2012). Ample studies within Computer-Assisted Language Learning (CALL) arena show that applying different technologies into instruction has a myriad of advantages for the instruction. In this context, language learners are found to attend more to reading tasks (Lan et al., 2007); collaboration among them is encouraged and facilitated (Kessler \& Bikowski, 2010); and more student-made activities are created (Yoon, 2008). In this way the participants' interest in and attitudes towards language learning enhanced in comparison to traditional courses (Hsieh et al., 2017) and they became more engaged in the process of learning (Khanova et al., 2015).

Further, mid-tech FI helped students attend the class well-prepared and thus the time of the class was spent on higher order cognitive activities rather than just focusing a lot 
on language forms. The flipped approach reverses the Bloom's taxonomy of cognitive activities while the lower order cognitive activities including understanding and remembering are carried out before the class and learners have a lot of time for learning deeply before entering the class (Khadri Ahmed, 2016). Afterwards, the cognitive activities of upper levels including applying, analysing, evaluating and creating are carried out by the presence and support of the instructor and other students in the class time. This contributed to more positive attitudes towards the instruction and more in-depth learning was gained (Kheirabadi, 2017).

Also, the mid-tech flipped group benefited from multimodal input that contributed substantially to the reduction of the load of information processing. Based on cognitive load theory, when the load of the learning task is more than the capacity of the learner's working memory, the learner feels cognitively overloaded and exhausted and may ultimately lose his/her interest in pursuing learning (Sweller et al., 2011). It is well known that this type of cognitive load, i.e., extraneous load, can be managed by the way the teaching materials are designed and delivered particularly in teaching a difficult subject matter. As multimodal instructional materials were prepared and given to mid-tech flipped group before the class phase, the students could manage the load of the learning tasks and thus the capacity of their working memory increased. This may have led to the reduction of task load and thus the ground was fully prepared for active learning in the in-class phase.

The finding is in agreement with a few studies done on technology-enhanced FI suggesting that by applying emerging technologies such as social networks, mobile-assisted learning systems, and student response systems in flipped classes, an increase in language learning outcomes is guaranteed (Hsieh et al., 2016; Hung, 2017). It is also found that when interactive learning and online support are deployed together in a flipped classroom, better achievement is gained (Strayer, 2012). The finding of the current study is also supported by previous research indicating that FI is a suitable instructional approach to be used in a higher education context (Al-Harbi \& Alshumaimeri, 2016; Hsieh et al., 2017) as it has positive effects on some teaching factors including self-regulated strategies (Ng, 2018), attitudes (Vaezi et al., 2019), and learning self-efficiency (Thai et al., 2017). More specifically, the finding corroborates what is suggested by language instructors that FI is an appropriate approach to be used in teaching English in undergraduate courses (Vaezi et al., 2019).

The findings also support those few studies that took the very first steps of comparing different flipped class conditions and reported that the way the instructional content is prepared by different technologies (Shyr \& Chen, 2018) and how it is incorporated into the cycle of teaching (Hung, 2015, 2017; Jensen et al., 2018) can make a difference in the effects of FI on learning outcomes.

\section{Effects of mid-tech Fl on reading proficiency considering the levels of impulsivity}

Examining the levels of impulsivity of the participants revealed that the type of instruction did not have any significant effect on the improvement of reading proficiency of students with different levels of impulsivity. However, probing into the descriptive statistics showed that students of the mid-tech FI with different levels of impulsivity performed almost equally in the post-test and outperformed their counterparts in other classes. 
This shows that mid-tech FI could address the needs of all three groups and is a much better instruction for learners with diverse cognitive styles. The reason for this can be related to the underlying framework of a flipped class and computer-assisted instruction (CAI) as both have been established and strengthened based on the main premise of personalized instruction and addressing individual differences (e.g., Bergmann \& Sams, 2012; Rahimi, 2015). This shows that while impulsivity/reflectivity divides "individuals into impulsive, who reach decisions quickly and spontaneously, which in turn entails a number of incorrect responses, and reflective who, in contrast, make fewer mistakes as a result of taking more time before providing the response" (Michonska-Stadnik, 2013, p. 139), appropriate personalized instruction such as mid-tech FI can fulfil the learning condition of either groups of the learners and help them learn to their maximum potential. This is actually in line with those studies that set forth that impulsiveness and using technology, especially using computers for work and spending more time on the Internet, are associated (Everton et al., 2005). High impulsiveness is even reported to be associated with pathological use of technology and particularly the Internet use hours (Morahan-Martin \& Schumacher, 2000). As impulsive people show greater variability of performance and faster cognitive tempo (Stanford et al., 2009), they might have benefited more from the mid-tech FI that gave them free access to using the website and a variety of online resources before the class and thus they could manage their learning based on their own preferences.

At the same time mid-tech FI was also found to be useful for participants who were more controlled and reflective. The mid-tech FI gave these students the opportunity to spend quality time to elaborate on the learning content and think about how to do the activities before the class to prepare themselves for the in-class phase via a lot of online instructional materials. It is known that reflective personalities have active minds and enjoy spending quality time on thinking and deep understanding of the issues. They spend a lot of time to make sense of events and experiences. They focus on the content and as a result, the pre-class phase of the flipped classroom gave these learners chances of concentration on the new lesson and they had time to deeply understand the materials and were prepared for the class time as reflectivity is "associated with active, directed and controlled search for the information" (Matczak, 1992, p. 37, as cited in MichonskaStadnik, 2013, p. 139). Further, as these learners enjoy listening to others, the collaborative activities of the in-class phase helped them learn better and remember the learned materials for a longer period of time.

Although no study has been done on the effect of FI on learning gains of language learners with different levels of impulsivity in English for general or academic purposes, it can be said that the finding generally corroborates research on the effectiveness of FI on language learning while diversity of learners and their preferences are taken into account (e.g. Bakla, 2018; Hsieh et al., 2017), supporting the fact that FI is the right instructional approach for language teaching from both theoretical and pedagogical standpoints (Mehring, 2018).

\section{Qualitative data analysis}

The findings of the qualitative data analysis showed that the participants had generally positive attitudes towards FI. The positive attitudes were found to be the result of 
'on-the-go learning' feature of the course and its capability in promoting learning outcomes in a GE course. The advantages of mobile learning are evident in the literature as mobile learning can provide easyaccess to instruction anytime and anywhere (KukulskaHulme, \& Shield, 2008). Providing a variety of content and easiness of carrying them everywhere gave students this opportunity to learn English more easily and with less pressure. Another positive aspect of FI that the participants highlighted was having a private tutor at home to help them tackle their problems with learning. Personalized instruction, as the main goal of FI, can create positive attitudes towards learning and lead to supportive learning environments (Vaezi et al., 2019). In this student-centred classroom, an active learning environment is fostered and students are challenged and assisted to do their best as learning tasks are customized to align with each student's interests, needs, and strengths.

In spite of these positive attitudes, some reservations existed with regard to using this approach in GE classes. English as the medium of instruction and the high load of learning materials were among the most focal points the students mentioned. One main reason of such negative attitudes is the unfamiliarity of students with the flipped approach. The sustained use of FI in GE courses would solve these difficulties as the needs of diverse groups of leaners would be addressed appropriately and as the result of this study showed their mastery of the content would increase ultimately.

Students' perceptions of their learning in flipped classes showed that having instructional content at hand has increased their attention to and concentration on the content. In addition, this type of instruction has brought joy and pleasure to their learning. Literature shows that applying images along with words decreases the overwhelming nature of reading and processing texts and can help learners cope with the task difficulty and load. A sensory and authentic learning experience can be provided by multimedia that presents a greater possibility for deeper learning (Lindfors, 1987; Mayer, 2003). Moreover, the students expected the teacher to spend more time on preparing high quality instructional materials. Considering the limited budget, the instructors have for materials development, this demands collaboration from the instructional departments of the universities to support flipped classes. Otherwise, the high load of materials development would discourage applying this innovative instructional approach in university courses.

\section{Conclusions}

In the last two decades, FI has been practiced and researched in many different educational contexts highlighting its tremendous potential for the stakeholders of the education system. Although substantial evidence supports the fact that FI can improve learning outcomes, satisfaction, motivation, critical thinking skills, retention, and creativity (Akçayıra \& Akçayırb, 2018), certain grave concerns related to the role of technology in preparing the content and the benefits of diverse groups of learners from FI are not yet fully addressed.

To fill this gap, the current study first set a continuum to differentiate technologies utilized for FI content preparation and delivery by a critical review of the literature. Then, based on the deduced model, two FI conditions, namely low-tech and mid-tech FI, were 
compared with a blended course and a conventional class to probe into participants' learning gains in general and when their degree of impulsivity was considered.

The findings were consistent with a few other studies and revealed that FI is not an inflexible instructional approach; and using different techniques and technologies for content preparation and delivery in FI may result in better learning achievement (Jensen et al., 2018). This may draw the attention of educationists to the importance of the quality of flipped course materials and that FI should be planned carefully to promote higher learning and more satisfaction with the course. There is, however, a need for more flipped classroom research to explore the advantages other technologies may offer for this innovative approach, particularly Intelligent Tutoring Systems that promote patterns of computer-human interaction intelligently by taking into account the dynamics of peoples' characteristics and behaviour.

Notably, the findings yielded illuminating insights into the role of technology in materials development in FI and how this complex issue can affect the learning gains of participants with diverse cognitive styles. In spite of the fact that impulsive and reflective learners are essentially different in their problem solving and task completion tempo, the FI with more integrated and interrelated instructional contents was found to be beneficial for both groups. A few studies have accentuated the fact that FI assists individualized learning (González-Gómez et al., 2016); and by what was found here it could be said that technology-enhanced FI could support individual learning even more. However, the scarcity of empirical evidence on this topic calls for further research to shed more light on the assumption that incorporating more complex technologies into FI would lead to more personalised learning among participants with diverse learning needs and preferences.

The result of qualitative data analysis provided great details about the way the students of two FI conditions perceived their learning experience. Minute differences were observed between the two groups' perceptions of the challenges and opportunities of FI, their learning in this context, and their feeling toward FI that could be overshadowed by participants' general satisfaction and technology acceptance attitudes. What was revealed through qualitative data analysis is generally in agreement with literature that FI promotes students' satisfaction (Hung, 2017), engagement (Fethi \& Marshall, 2018), and enjoyment (Wanner \& Palmer, 2015). What the finding of this study actually adds to the literature is that the level of all these variables could be dependent on the technologies that are used to prepare and deliver the content in FI, and how their affordances may promote attention and concentration, help learners manage their cognitive load, and ease the instruction through mobile learning. Additional research is absolutely needed to examine this assumption and explore the possibility of establishing causative relations between technology type and potential advantages of FI in education. In this framework, one line of study could focus on the suggested continuum of technology complexity for preparing the out-of-class content of FI, as this continuum is deduced based on reviewing the literature by the researchers of the current study, and its generalizability is open to further research. 
European Framework of Reference; ESOL: English as a second language; ESP: English for specific purposes; Fl: Flipped instruction; GE: General English; ITS: Intelligent tutoring systems; LMS: Learning management system.

\section{Acknowledgements}

Not applicable.

\section{Authors' contribution}

SZ carried out the study and gathered the data. MR conceptualized, designed and supervised the research; and drafted, wrote, reviewed and edited the manuscript. AM gave advice on how to carry out the study. All authors read and approved the final manuscript.

\section{Funding}

No specific funding has been received in collection, analysis, and interpretation of the data and in writing the manuscript.

\section{Availability of data and materials}

Since mixed methods approach was used in this study, most parts of the data are shared with the readers in the manuscript.

\section{Consent to participate}

Not applicable.

\section{Competing interest}

The authors declare that they have no competing interest.

\section{Author details}

${ }^{1}$ Islamic Azad University, South Tehran Branch, Tehran, Iran. ${ }^{2}$ English Department, Faculty of Humanities, Shahid Rajaee Teacher Training University, Lavizan, Tehran 1678815811, Iran.

Received: 31 January 2021 Accepted: 15 June 2021

Published online: 23 August 2021

\section{References}

Akçayıra, G., \& Akçayırb, M. (2018). The flipped classroom: A review of its advantages and challenges. Computers \& Education, 126, 334-345.

Al-Harbi, S. S., \& Alshumaimeri, Y. A. (2016). The flipped classroom impact in grammar class on EFL Saudi secondary school students' performances and attitudes. English Language Teaching, 9(10), 60-80.

Amiryousefi, M. (2019). The incorporation of flipped learning into conventional classes to enhance EFL learners' L2 speaking, L2 listening, and engagement. Innovation in Language Learning and Teaching, 13(2), 147-161.

Arianakia, E., \& Hassani, J. (2014). Impulsivity and cognitive emotion regulation strategies in patients with bipolar-and major depressive disorders. Advances in Cognitive Science, 16(2), 1-10.

Awidi, I. T., \& Paynter, M. (2019). The impact of a flipped classroom approach on student learning experience. Computers \& Education, 128, 269-283.

Bakla, A. (2018). Learner-generated materials in a flipped pronunciation class: A sequential explanatory mixed-methods study. Computers \& Education, 125, 14-38.

Bergmann, J., \& Sams, A. (2012). Flip your classroom: Reach every student in every class every day. ISTE \& ASCD.

Bishop, J.L., \& Verleger, M.A. (2013). The flipped classroom: A survey of the research. In Proceedings of the $120^{\text {th }}$ ASEE annual conference \& exposition. Atlanta, GA: American Society for Engineering Education.

Brown, A. F. (2018). Implementing the flipped classroom: Challenges and strategies. In J. Mehring \& A. Leis (Eds.), Innovations in flipping the language classroom (pp. 11-21). Springer.

Brown, H. D. (2018). Principles of language learning and teaching. Pearson.

Brunsell, E., \& Horejsi, M. (2013). Science 2.0: A flipped classroom in action. The Science Teacher, 80(2), 8.

Buitrago, C. R., \& Díaz, J. (2018). Flipping your writing lessons: Optimizing time in your EFL writing classroom. In J. Mehring \& A. Leis (Eds.), Innovations in flipping the language classroom (pp. 69-92). Springer.

Çakıroğlu, Ü., \& Öztürk, M. (2017). Flipped classroom with problem based activities: Exploring self-regulated learning in a programming language course. Journal of Educational Technology \& Society, 20(1), 337-349.

Chapelle, C., \& Fraiser, T. (2009). Individual learner differences in CALL: The Field Independence/Dependence (FID) construct. CALICO Journal, 26(2), 246-266.

Chen, Y. T., Liou, S., \& Chen, L. F. (2019). The relationships among gender, cognitive styles, learning strategies, and learning performance in the flipped classroom. International Journal of Human-Computer Interaction, 35(4-5), 395-403.

Chen, Y., Wang, Y., Kinshuk, \& Chen, N.S. (2014). Is FLIP enough? Or should we use the FLIPPED model instead? Computers \& Education, 79, 16-27.

Crawford, S. R., \& Senecal, J. (2017). Tools of the trade: What do you need to flip? In L. S. Green, J. R. Banas, \& R. A. Perkins (Eds.), The flipped college classroom: Conceptualized and re-conceptualized (pp. 37-50). Springer.

Ekhtiari, H., Safaei, H., Esmaeeli, D., Atefvahid, M. K., Edalati, H., \& Mokri, A. (2008). Reliability and validity of Persian versions of Eysenck, Barratt, Dickman and Zucherman questionnaires in assessing risky and impulsive behaviors. Iranian Journal of Psychiatry \& Clinical Psychology, 14(3), 326-336.

Ellis, R. (2008). The study of second language acquisition (2nd ed.). Oxford University Press.

Everton, W., Mastrangelo, P., \& Jolton, J. (2005). Personality correlates of employees' personal use of work computers. CyberPsychology Behavior, 8(2), 143-153. 
Fadol, Y., Aldamen, H., \& Saadullah, S. (2018). A comparative analysis of flipped, online and traditional teaching: A case of female Middle Eastern management students. The International Journal of Management Education, 16(2), 266-280.

Fethi, K., \& Marshall, H. W. (2018). Flipping movies for dynamic engagement. In J. Mehring \& A. Leis (Eds.), Innovations in flipping the language classroom (pp. 185-202). Springer.

Gilboy, M. B., Heinerichs, S., \& Pazzaglia, G. (2015). Enhancing student engagement using the flipped classroom. Journal of Nutrition Education and Behavior, 47(1), 109-114.

Goedhart, N. S., Blignaut-van Westrhenen, N., Moser, C., \& Zweekhorst, M. B. M. (2019). The flipped classroom: Supporting a diverse group of students in their learning. Learning Environments Research, 22, 297-310.

González-Gómez, D., Jeong, J. S., Airado Rodríguez, D., \& Cañada-Cañada, F. (2016). Performance and perception in the flipped learning model: An initial approach to evaluate the effectiveness of a new teaching methodology in a general science classroom. Journal of Science Education and Technology, 25(3), 450-459.

Haghighi, H., Jafarigohar, M., Khoshsima, H., \& Vahdany, F. (2019). Impact of flipped classroom on EFL learners' appropriate use of refusal: Achievement, participation, perception. Computer Assisted Lanquage Learning, 32(3), 261-293.

Han, E., \& Klein, K. (2019). Pre-class learning methods for flipped classrooms. American Journal of Pharmaceutical Education, 83(1), 6922.

He, W., Holton, A., Farkas, G., \& Warschauer, M. (2016). The effects of flipped instruction on out-of-class study time, exam performance, and student perceptions. Learning \& Instruction, 45, 61-71.

Hsieh, J. S. C., Huang, Y. M., \& Wu, W. C. V. (2017). Technological acceptance of LINE in flipped EFL oral training. Computers in Human Behaviour, 70, 178-190.

Hsieh, J. S. C., Wu, W. C. V., \& Marek, M. (2016). Using the flipped classroom to enhance EFL learning. Computer Assisted Language Learning, 30(1-2), 1-21.

Hung, H. T. (2015). Flipping the classroom for English language learners to foster active learning. Computer Assisted Language Learning, 28(1), 81-96.

Hung, H. T. (2017). The integration of a student response system in flipped classroom. Language Learning \& Technology, 21(1), 16-27.

Jensen, L., Holt, E., Sowards, J., Ogden, H., \& West, R. (2018). Investigating strategies for pre-class content learning in a flipped classroom. Journal of Science Education and Technology, 27, 523-535.

Kasikhan, H. R. (2016). Revive your general English. Jungle Publications.

Kessler, G., \& Bikowski, D. (2010). Developing collaborative autonomous learning abilities in computer mediated language learning: Attention to meaning among students in wiki space. Computer Assisted Language Learning, 23(1), 41-58.

Khadri Ahmed, H. O. (2016). Flipped learning as a new educational paradigm: An analytical critical study. European Scientific Journal, 12(10), 417-444.

Khanova, J., Roth, M. T., Rodgers, J. E., \& McLaughlin, J. E. (2015). Student experiences across multiple flipped courses in a single curriculum. Medical Education, 49(10), 1038-1048.

Kheirabadi, R. (2017). The impact of flipped classroom model on teaching English grammar at 10th grade of high school. Quarterly Journal of Educational Innovations, 16(64), 141-162.

Knyazev, G. G., \& Slobodskaya, H. R. (2006). Personality types and behavioral activation and inhibition in adolescents. Personality and Individual Differences, 41, 1385-1395.

Kukulska-Hulme, A., \& Shield, L. (2008). An overview of mobile assisted language learning: From content delivery to supported collaboration and interaction. ReCALL, 20(3), 271-289.

Lage, M., Platt, G., \& Treglia, M. (2000). Inverting the classroom: A gateway to creating an inclusive learning environment. Journal of Economic Education, 31(1), 30-43.

Lan, Y. J., Sung, Y. T., \& Chang, K. E. (2007). A mobile-device-supported peer-assisted learning system for collaborative early EFL reading. Lanquage Learning \& Technology, 11(3), 130-151.

Lindfors, J. (1987). Children's language and learning. Prentice-Hall.

Martin, S., Farnan, J., \& Arora, V. (2013). FUTURE: New strategies for hospitalists to overcome challenges in teaching and today's wards. Journal of Hospital Medicine, 8(7), 409-413.

Mayer, R. E. (2003). The promise of multimedia learning: Using the same instructional design methods across different media. Learning and Instruction, 13, 25-139.

Matczak, A. (1992). Test Porównywania Znanych Kształtów (MFF) J. Kagana. Warszawa: Pracownia Testów Psychologicznych Polskiego Towarzystwa Psychologicznego.

Mehring, J. (2018). The flipped classroom. In J. Mehring \& A. Leis (Eds.), Innovations in flipping the language classroom (pp. $1-10)$. Springer.

Michonska-Stadnik, A. (2013). The relationship between impulsive/reflective cognitive style and success in grammar acquisition in English as a foreign language. In K. Drozdzial \& M. Pawlak (Eds.), Psycholinguistic and sociolinguistic perspectives on second language learning and teaching (pp. 137-149). Springer.

Mohamed, H., \& Lamia, M. (2018). Implementing flipped classroom that used an intelligent tutoring system into learning process. Computers \& Education, 124, 62-76.

Morahan-Martin, J., \& Schumacher, P. (2000). Incidence and correlates of pathological Internet use among college students. Computers in Human Behavior, 16(31), 13-29.

Moravec, M., Williams, A., Aguilar-Roca, N., \& O'Dowd, D. (2010). Learn before lecture: A strategy that improves learning outcomes in a large introductory biology class. CBE-Life Sciences Education, 9(4), 473-481.

Ng, E. M. W. (2018). Integrating self-regulation principles with flipped classroom pedagogy for first year university students. Computers \& Education, 126, 65-74.

Patton, J. H., Stanford, M. S., \& Barratt, E. S. (1995). Factor structure of the Barratt impulsiveness scale. Journal of Clinical Psychology, 6, 768-774.

Phuong, L. T. A. (2002). Problems and solutions for general English classes at junior classes. Teacher's Edition, 18-22. Retrieved March 2019 from http://www.nzdl.org/gsdl/collect/iteratu/index/assoc/HASH7432.dir/doc.pdf

Cambridge English Qualifications. B1 Preliminary: Handbook for teachers for exams from 2020 (2020). https://cambridgeexams.ch/sites/default/files/b1-preliminary-handbook-2020.pdf. Accessed Nov 2020.

Rahimi, M. (Ed.). (2015). Handbook of research on individual differences in computer-assisted language learning. IGI Global. 
Ramirez, M. (2018). In-class flip: Flipping a literature class for student-centered learning. In J. Mehring \& A. Leis (Eds.), Innovations in flipping the language classroom (pp. 93-104). Springer.

Riding, R., \& Rayner, S. (1998). Cognitive styles and learning strategies: Understanding style differences in learning and behavior. David Fulton Publishers.

Saldana, J. (2013). The coding manual for qualitative research. Sage.

See, S., \& Conry, J. M. (2014). Flip my class! A faculty development demonstration of a flipped-classroom. Current in Pharmacy Teaching \& Learning, 6, 585-588.

Sengel, E. (2016). To FLIP or not to FLIP: Comparative case study in higher education in Turkey. Computers in Human Behavior, 64, 547-555.

Shyr, W., \& Chen, C. H. (2018). Designing a technology-enhanced flipped learning system to facilitate students'selfregulation and performance. Journal of Computer Assisted Learning, 34(1), 53-62.

Soltani, K., Hadidi, N., \& Seifoori, Z. (2015). Iranian EFL learners' reflectivity/impulsivity styles and their metacognitive awareness of reading strategy use across gender. Journal of Education \& Assessment, 8(31), 103-124.

Stanford, M. S., Mathias, C. W., Dougherty, D. M., Lake, S. L., Anderson, N. E., \& Patton, J. H. (2009). Fifty years of the Barratt Impulsiveness Scale: An update and review. Personality and Individual Differences, 47, 385-395.

Strayer, J. (2012). How learning in an inverted classroom influences cooperation, innovation and task orientation. Learning Environments Research, 15, 171-193.

Strelan, P., Osborn, A., \& Palmer, E. (2020). The flipped classroom: A meta-analysis of effects on student performance across disciplines and education levels. Educational Research Review, 30, 100314.

Sweller, J., Ayres, P., \& Kalyuga, S. (2011). Cognitive load theory. Springer.

Thai, N. T. T., Wever, B., \& Valcke, M. (2017). The impact of a flipped classroom design on learning performance in higher education: Looking for the best "blend" of lectures and guiding questions with feedback. Computers \& Education, $107,113-126$.

Vaezi, R., Afghari, A., \& Lotfi, A. (2019). Flipped teaching: Iranian students'and teachers' perceptions. Applied Research on English Language, 8(1), 139-164.

van Alten, D., Phielix, C., Janssen, J., \& Kester, L. (2020). Self-regulated learning support in flipped learning videos enhances learning outcomes. Computers \& Education, 158, 104000

Walsh, J., \& Rísquez, A. (2020). Using cluster analysis to explore the engagement with a flipped classroom of native and non-native English-speaking management students. The International Journal of Management Education, 18, 100381.

Wanner, T., \& Palmer, E. (2015). Personalising learning: Exploring student and teacher perceptions about flexible learning and assessment in a flipped university course. Computers \& Education, 88, 354-369.

Warden, A. (2016). Investigating the use of a flipped approach to grammar input in an English as a Foreign Language classroom (Unpublished master's thesis). University of Chichester, UK.

Yilmaz, R. (2017). Exploring the role of e-learning readiness on student satisfaction and motivation in flipped classroom. Computers in Human Behaviour, 70, 251-260.

Yoon, H. (2008). More than a linguistic reference: The influence of corpus technology on L2 academic writing. Language Learning \& Technology, 12(2), 31-48.

Zainuddin, Z. (2018). Students'learning performance and perceived motivation in gamified flipped-class instruction. Computers \& Education, 126, 75-88.

Zarrinabadi, N., \& Ebrahimi, A. (2019). Increasing peer collaborative dialogue using a flipped classroom strategy. Innovation in Language Learning and Teaching, 13(3), 267-276.

Zhang, H., Li, J., Jiao, L., Ma, W., \& Guan, C. (2016). The adjustment and effects of vocabulary teaching strategies in flipped classroom. Creative Education, 7, 1966-1973.

\section{Publisher's Note}

Springer Nature remains neutral with regard to jurisdictional claims in published maps and institutional affiliations.

\section{Submit your manuscript to a SpringerOpen ${ }^{\circ}$ journal and benefit from:}

- Convenient online submission

- Rigorous peer review

- Open access: articles freely available online

- High visibility within the field

- Retaining the copyright to your article

Submit your next manuscript at $\boldsymbol{\nabla}$ springeropen.com 